\title{
INTRODUCTION TO THE SYMPOSIUM ON NEW CHALLENGES IN WEAPONS INSPECTION
}

\author{
Jean Galbraith
}

This symposium addresses challenges relating to weapons inspection. The common thread among the contributions is a concern that the future of weapons inspection may prove even more difficult than its past. It has always been hard to "trust but verify" - and it is all the harder in a world where more actors are involved, trust is frayed, disinformation is rampant, and technology has added new weapons. The leading scholars and practitioners contributing to this symposium detail these challenges and the prospects for addressing them. The seeds of hope mentioned here include technological shifts that may make some kinds of monitoring easier, the ongoing development of networks of experts, and the potential for new binding and non-binding international commitments related to weapons inspection.

The years immediately following the Cold War were golden times for arms control. The difficult though often productive negotiations that had characterized the Cold War era metamorphized into seized opportunities, including the signing and entry into force of the Chemical Weapons Convention. The Security Council, now more functional, could take up arms control and make weapons inspection an integral part of Resolution 687 at the end of the First Gulf War. The implementation of these and other new international commitments, in turn, built networks and pertinent forms of expertise.

Now, almost thirty years since the Cold War ended, the risks from conventional, biological, chemical, and nuclear weapons remain terrifyingly high, yet the international energy and ability to address them is not always evident. Non-state actors have joined rogue states as a major source of concern; cooperation has faded between the United States and Russia even as China's rising military power places strain on the traditional bipolar paradigm; and international threats like climate change and now COVID-19 appropriately occupy international bandwidth. Technological developments have had their inevitable double edge: more tools for monitoring but also more tools for concealment—and the arrival of cyber weapons.

The symposium begins with an essay by David Koplow of Georgetown University, who focuses on the creation of arms control commitments, with a particular emphasis on what could lie ahead in the domains of air and space. ${ }^{1}$ Koplow begins by framing arms control agreements as typically built from three conceptual components: first, substantive prohibitions; second, the means of monitoring; and third, legal commitments sufficient to effectuate the other two components. He describes the interactions between these components in earlier international treaties and considers the prospects for future ones. He describes the special importance of air for monitoring, as embodied in the Open Skies Treaty from which the United States has now regrettably withdrawn and whose future remains more generally in doubt. With respect to space, he notes that it is both an arena in which weapons could be deployed and a vantage point for monitoring the development and deployment of weapons on earth.

* Professor, University of Pennsylvania Carey Law School, Philadelphia, Pennsylvania, United States.

${ }^{1}$ David A. Koplow, What are You Lookin' At? Aerial and Space Observation for Arms Control, 115 AJIL Unbound 89 (2021).

(C) Jean Galbraith 2021. This is an Open Access article, distributed under the terms of the Creative Commons Attribution licence (http://creativecommons.org/licenses/by/4.0/), which permits unrestricted re-use, distribution, and reproduction in any medium, provided the original work is properly cited. 
He urges the development of a treaty-based institution that uses satellites to monitor compliance with arms control agreements.

Åke Sellström's contribution draws from the past to reflect on the future. ${ }^{2}$ The former Chief Inspector for the United Nations Special Commission created with respect to Iraq by Resolution 687, and the head of a UN factfinding mission regarding the use of chemical weapons in Syria, Sellström offers some lessons learned from his extraordinary practical experience. He describes the many challenges of weapons inspection on the ground and emphasizes the need for international organizations involved in inspections to have staff who are both highly qualified and able to command the respect of nations who view arms control as a West-dominated enterprise rather than a universal objective. He closes by reflecting on the challenges of achieving success in a domain characterized by an absence of trust.

Jennie Gromoll, a senior advisor in the U.S. State Department's Bureau of International Security and Nonproliferation, considers the challenge of building future expertise with respect to weapons inspection. ${ }^{3}$ The negotiation of arms control treaties had once been a pipeline for future inspectors-as well as a forum for building cross-national personal relationships_-but the Conference on Disarmament is no longer the active space for negotiation that it used to be. Arms control has lost some ground as well in settings outside of government, such as university programs, as other issues have come to occupy funding and attention. She identifies ongoing initiatives of promise, including the International Partnership for Nuclear Disarmament Verification and the EU Non-proliferation and Disarmament Consortium.

The challenges ahead for weapons inspection include not only making sure there are talented people to implement it, but also dealing with those people who would hinder it. Mallory Stewart, at the time of writing the Director of the Cooperative Monitoring Center at Sandia National Laboratories, describes the regrettable success of disinformation campaigns aimed at undercutting Syria's accountability for uses of chemical weapons. ${ }^{4}$ Recognizing that there are no easy fixes, she identifies some steps to try to mitigate these campaigns. Like other contributors to this symposium, she emphasizes the importance of efforts to build trust, both among experts across different countries and between experts and the broader population.

The final contribution to the symposium, with a focus on cyber, comes from Przemysław Roguski of Jagiellonian University. ${ }^{5}$ He notes the unique difficulties faced in monitoring cyber weapons, including the mix of public and private actors involved, their diffuse nature, and the potential for these weapons to have dual use as tools of surveillance and as sources of harm. Considering the path forward, he suggests that, to the extent progress is possible, it will rest initially in soft law conversations around shared principles and on the development of better technology for cybersecurity. He notes efforts underway to develop rules of responsible behavior in cyberspace and also efforts to set forth standards of due diligence for those that might be on the receiving end of a cyberattack.

Collectively, these essays could not be more timely. In the United States, the Biden administration has an immediate to-do list in relation to arms control. In addition to the issue of extending the New START treaty, the administration will doubtless consider rejoining the Open Skies Treaty (if it can negotiate successfully to prevent Russian withdrawal) and reopening conversations with Iran to try to reinstate something along the lines of the Joint Comprehensive Plan of Action. But beyond these actions-largely damage control from the Trump administration - it remains to be seen what priorities will lie ahead. The essays here remind us that in addition to thinking

\footnotetext{
2 Åke Sellström, Lessons from Weapons Inspections in Iraq and Syria, 115 AJIL UnBound 95 (2021).

3 Jennie Gromoll, The Fading Pipeline: Preparing the Next Generation of Weapons Inspectors, 115 AJIL UnBound 100 (2021).

${ }^{4}$ Mallory Stewart, Defending Weapons Inspections from the Effects of Disinformation, 115 AJIL UNBOund 106 (2021).

${ }^{5}$ Przemysław Roguski, An Inspection Regime for Cyber Weapons: A Challenge Too Far?, 115 AJIL Unbound 111 (2021).
} 
about big-ticket items like the negotiation of new, binding international commitments, it is important to invest in less dramatic steps. These include the efforts to enhance expertise and networks, to support international organizations engaged in weapons inspection, and to engage in negotiation of soft law principles and commitments. 